\title{
World War I in the Historical Imagination of W. E. B. Du Bois
}

\author{
Chad Williams
}

W. E. B. Du Bois stands as one of the most celebrated and studied African Americans in United States history. Nevertheless, Du Bois's substantial body of writings on World War I has received little scholarly attention. This article explores Du Bois's published and unpublished work, revealing the centrality of World War I to Du Bois's life and historical imagination. Du Bois devoted decades to writing about and grappling with the historical legacy of World War I for African Americans, broadly, and for himself, individually. His inability to find both collective and personal redemptive meaning in the war reflects his struggle to reconcile the tension between history and memory, as well as the still contested place of World War I in African American history.

"How great a failure and a failure in what does the World War betoken?"

-W. E. B. Du Bois, Darkwater (1920)

The study of African Americans and World War I has experienced an impressive resurgence. Since the early 2000s, scholars have bridged longstanding divides between social history, military history, cultural history, and civil rights history, opening new doors for understanding the place of the war in the individual and collective memories of black people in the United States and beyond. ${ }^{1}$ W. E. B. Du Bois would be pleased with this historiographical turn of events. The

\footnotetext{
Many thanks, first and foremost, to Brooke Blower and Sarah Phillips for encouraging me to submit this article to $M A H$ and for their editorial leadership. They were part of a writing group of Boston-area historians who read an early draft of this article with great care and offered constructive criticism. The observations and suggestions from the three anonymous reviewers made this article much stronger. Audiences at Duke University, Hamilton College, SUNY Binghamton, and Vanderbilt University, where I have presented aspects of this work, provided me with helpful feedback. A wonderful conversation with colleagues at the Radcliffe Institute for Advance Study at Harvard University pushed me to think through final revisions. Finally, I am deeply indebted to David Levering Lewis and Jennifer Keene for their scholarship and professional support, and for indulging me in conversations about W. E. B. Du Bois and World War I over the years.

${ }^{1}$ A number of popular "histories" of African Americans in the war were published immediately after the armistice. For instance, see Kelly Miller, Kelly Miller's Authentic History of the Negro in the World War (Washington, DC, 1919); Emmett J. Scott, Scott's Official History of the American Negro in the World War (Chicago, 1919); and W. Allison Sweeny, History of the American Negro in the Great World War: His Splendid Record in the Battle Zones of Europe (Chicago, 1919). Until the twenty-first century, Arthur Barbeau and Florette Henri's The Unknown Soldiers, originally published in 1974, stood as the lone scholarly book on African Americans in World War I. Arthur E. Barbeau and Florette Henri, The Unknown Soldiers: African-American Troops in World War I (Philadelphia, 1974; New York, 1996). Key recent scholarship includes Mark Ellis, Race, War, and Surveillance: African Americans and the United States Government during World War I (Bloomington, IN, 2001); Theodore Kornweibel, Jr., "Investigate Everything": Federal Efforts to Compel Black Loyalty during World War I (Bloomington, IN, 2002); Frank E. Roberts, The American Foreign Legion: Black Soldiers of the 93d in World War I (Annapolis, MD, 2004); Richard Slotkin, Lost Battalions: The Great War and the Crisis of American Nationality (New York, 2005); Mark Whalan, The Great War and the Culture of the New Negro (Gainesville, (c) The Author(s) 2018. Published by Cambridge University Press
} 
acclaimed scholar and civil rights leader, who until his dying breath fought for the cause of black freedom and equality, understood perhaps better than anyone else in his day the historical significance of World War I for African Americans and other peoples of African descent. Just as the war represented a watershed moment in the history of the modern world, it also constituted a formative period in Du Bois's personal, political, and intellectual life. Du Bois devoted decades to studying and writing about black participation in the First World War. Indeed, no other historical subject, with the possible exception of Reconstruction, consumed more of his time and intellectual energy.

It is therefore surprising that few works in the voluminous body of scholarship on Du Bois dwell on his longstanding interest in World War I. Whereas Du Bois's publications on slavery, the Civil War, and Reconstruction are acknowledged and hailed as prophetic, his extensive writings on World War I remain largely ignored. ${ }^{2}$ Scholarly discussions of Du Bois and the First World War have overwhelmingly focused on his stance supporting the American war effort and the controversial "Close Ranks" editorial he wrote for the July 1918 issue of The Crisis. ${ }^{3}$ Lost in this preoccupation is any systematic analysis of Du Bois's writings-published and unpublished-produced during and especially after the war. This is in part a striking reflection of the marginalized place of World War I in African American historiography. But this lacuna also reflects the continued need for scholars to fully examine the dynamic nature of $\mathrm{Du}$ Bois's historical imagination and the diverse range of works that flowed from it.

FL, 2008); Adriane Lentz-Smith, Freedom Struggles: African Americans and World War I (Cambridge, MA, 2009); Peter Nelson, A More Unbending Battle: The Harlem Hellfighters' Struggle for Freedom in WWI and Equality at Home (New York, 2009); Chad L. Williams, Torchbearers of Democracy: African American Soldiers in the World War I Era (Chapel Hill, NC, 2010); Robert H. Ferrell, Unjustly Dishonored: An African American Division in World War I (Columbia, MO, 2011); Nina Mjagkij, Loyalty in Time of Trial: The African American Experience during World War I (Lanham, MD, 2011); Jeffrey T. Sammons and John H. Morrow, Jr., Harlem's Rattlers and the Great War: The Undaunted 369th Infantry Regiment and the African American Quest for Equality (Lawrence, KS, 2014); Adam P. Wilson, African American Officers of World War I: A Vanguard of Equality in War and Beyond (Jefferson, NC, 2015); W. Douglas Fisher and Joann H. Buckley, African American Doctors of World War I: The Lives of 104 Volunteers (Jefferson, NC, 2016); and Royal A. Christian, Porter, Steward, Citizen: An African American's Memoir of World War I, ed. Pellom McDaniels III (New York, 2017). In addition to her book Doughboys, the Great War, and the Remaking of America (Baltimore, 2006), which devotes significant attention to African American soldiers, historian Jennifer D. Keene has produced several articles and essays on the black experience in the war. For instance, see "French and American Racial Stereotypes during the First World War," in National Stereotypes in Perspective: Frenchmen in America, Americans in France, ed. William Chew (Amsterdam, 2001), 261-81; "Protest and Disability: A New Look at African American Soldiers during the First World War," in Warfare and Belligerence: Perspectives in First World War Studies, ed. Pierre Purseigle (Leiden, Netherlands, 2005), 213-41; "The Memory of the Great War in the African American Community," in Unknown Soldiers: The American Expeditionary Forces in Memory and Remembrance, ed. Mark Snell (Kent, $\mathrm{OH}, 2008)$, 60-79; "Images of Racial Pride: African American Propaganda Posters in the First World War," in Picture This! Reading World War I Posters, ed. Pearl James (Lincoln, NE, 2009), 207-40; and "The Long Journey Home: African American World War I Veterans and Veterans' Policies,” in Veterans' Policies, Veterans' Politics: New Perspectives on Veterans in the Modern United States, ed. Stephen R. Ortiz (Gainesville, FL, 2012), 146-70.

${ }^{2}$ Notable exceptions include Jennifer D. Keene, "W. E. B. Du Bois and the Wounded World," Peace and Change 26, no. 2 (Apr. 2001): 135-52; David Levering Lewis, W. E. B. Du Bois: Biography of a Race, 1868-1919 (New York, 1993), 561-2, 572 (hereafter W. E. B. Du Bois, Vol. 1); David Levering Lewis, W. E. B. Du Bois: The Fight of Equality and the American Century, 1919-1963 (New York, 2000) (hereafter W. E. B. Du Bois, Vol. 2); and Shane A. Smith, "The Crisis in the Great War: W. E. B. Du Bois and His Perception of African-American Participation in World War I," The Historian 70, no. 2 (Summer 2008): 239-62.

${ }^{3}$ For discussion of the "Close Ranks” controversy, see Mark Ellis, “Closing Ranks' and 'Seeking Honors': W. E. B. Du Bois in World War I," Journal of American History 79, no. 1 (June 1992): 96-124; Mark Ellis, “W. E. B. Du Bois and the Formation of Black Opinion in World War I: A Commentary on 'The Damnable Dilemma," Journal of American History 81, no. 4 (Mar. 1995): 1584-90; William Jordan, “The Damnable Dilemma': African-American Accommodation and Protest during World War I," Journal of American History 81, no. 4 (Mar. 1995): 1562-83; Lewis, W. E. B. Du Bois, Vol. 1, 552-60; Raymond Wolters, Du Bois and His Rivals (Columbia, MO, 2002). 
An exploration of Du Bois's remarkable corpus of journal articles, editorials in The Crisis, published books, and unpublished manuscripts sheds light on his understanding of World War I in both history and memory. The practice of history for Du Bois required challenging the "master narrative" and creating a counter-memory that revealed black people as "the central thread of American history." ${ }^{\prime 4}$ Du Bois's intellectual career and specific approach to history have been traditionally segmented according to his shifting ideological beliefs. ${ }^{5}$ This undervalues the intertwined social scientific, ethical, and political dimensions of his historicism that spanned all the stages of his career. Historian, sociologist, philosopher, essayist, novelist, playwright-W. E. B. Du Bois was many things. But, as many scholars have demonstrated, he was above all else an artist. ${ }^{6}$ And as an artist, Du Bois infused his work with a sense of imagination. Du Bois's particular sense of historical imagination was informed by his unique background and positionality as a black historian, by a view of the production of historical knowledge as a form of art with the power to transform both minds and souls, and by a belief that historical facts must address the problems of the contemporary world. ${ }^{7}$ For Du Bois, this entailed a commitment to reclaiming the past for African Americans in order to demonstrate its relevance to the present and using history to build a future in which white supremacy no longer existed and black people could fully embrace their humanity.

With the First World War, Du Bois found himself at the precarious intersection of history and memory. The war traumatized Du Bois. His support for the American war effort raised serious questions about his political and intellectual judgment; the disillusioning experiences of African American soldiers shook his faith in democracy; the resurgence of white supremacy domestically and on a global scale throughout the 1920s and 1930s left him searching for answers to what the war ultimately meant. As he always did, Du Bois attempted to use the fecundity of his mind and the clairvoyance of his pen to understand this historical moment and reveal its significance to the ongoing problem of the color-line. He had mixed results. Most notably, a proposed historical study of the black experience in the war, nearly twenty years in the making, failed to reach the public. But what Du Bois did produce provides remarkable insight not just into his own mind and evolving interpretation of World War I, but also what the war meant for African Americans more broadly-the sincere hopes they had for democracy in its aftermath, the intense frustration of aspirations unfulfilled, and the ongoing struggle, one that continues to this day, to have the history of black participation in the war accurately conveyed.

\section{"The past is the present": Du Bois as Historian}

In his 1947 book, The World and Africa, Du Bois recounted an exchange with a potential editor who, in considering one of his articles for publication, suggested that he "leave out

\footnotetext{
${ }^{4}$ David W. Blight, "W. E. B. Du Bois and the Struggle for American Historical Memory," in History \& Memory in African-American Culture, eds. Geneviève Fabre and Robert O’Meally (Oxford, 1994), 45-71, here 45-9; W. E. B. Du Bois, The Gift of Black Folk: The Negroes in the Making of America (Boston, 1924; New York, 2009 ), 57.

${ }^{5}$ See Robert Gregg, "Giant Steps: W. E. B. Du Bois and the Historical Enterprise," in W. E. B. Du Bois, Race, and the City: The Philadelphia Negro and Its Legacy, eds. Michael B. Katz and Thomas J. Sugrue (Philadelphia, 1998), 77-99; Arnold Rampersad, The Art and Imagination of W. E. B. Du Bois (Cambridge, MA, 1976), 32-5, 110, 228.

${ }^{6}$ See Rampersad, The Art and Imagination of W. E. B. Du Bois; Shawn Michelle Smith, Photography on the Color Line: W. E. B. Du Bois, Race, and Visual Culture (Durham, NC, 2004); and Amy Helene Kirschke, Art in Crisis: W. E. B. Du Bois and the Struggle for African American Identity and Memory (Bloomington, IN, 2007).

${ }^{7}$ The English philosopher R. G. Collingwood offers a useful theoretical framework for understanding historical imagination in his classic book The Idea of History (Oxford, 1946). I also draw from Thomas Holt's examination of the role of historical imagination in Du Bois's 1935 landmark book Black Reconstruction. Holt argues that Du Bois's radical historical revisionism was informed by an understanding of postwar black life first developed in his early sociological and literary writings that allowed him read against the racist secondary source scholarship of his day in lieu of archival research. Thomas C. Holt, “'A Story of Ordinary Human Beings': The Sources of Du Bois's Historical Imagination in Black Reconstruction," South Atlantic Quarterly 112, no. 3 (Summer 2013): 419-35.
} 
the history and come to the present." Nearly eighty years old and still incredulous, Du Bois wrote, "I felt like going to him over a thousand miles and taking him by the lapels and saying, 'Dear, dear jackass! Don't you understand that the past is the present; that without what was, nothing is?"'8 Throughout his long, multidimensional career, Du Bois never forgot that he was a historian. He received his Ph.D. from Harvard University in 1895 at a time when history was considered a social science. Despite his close relationship with Harvard luminaries such as William James, Josiah Royce, and George Santayana, he turned away from philosophy to embrace historical sociology and its applicability "for gathering and interpreting that body of facts which would apply to my program for the Negro." 9 Like many American historians of his day, Du Bois embraced the German school of historical economics, which prioritized the accumulation and analysis of factual evidence in order to reach conclusions about how human behavior and values shaped the economic organization of societies. Du Bois was heavily influenced by German scholars like Leopold von Ranke, Heinrich von Treitschke, and Gustav van Schmoller, having studied with the latter two during a life-changing stint at the University of Berlin from 1892 to $1894 .{ }^{10}$ At Harvard, the noted historian Albert Bushnell Hart served as his mentor. Hart likewise promoted Germanic historical methodology and facilitated Du Bois's deep internalization of a commitment to history as both a scientific and ethical quest for truth. ${ }^{11}$

$\mathrm{Du}$ Bois's earliest publications reflected his commitment to the social sciences and historical sociology. His doctoral thesis, "The Suppression of the African Slave Trade to the United States of America, 1638-1870," was rigorously documented and earned the distinction of being the first publication in the Harvard Historical Studies series. ${ }^{12}$ The 1899 landmark The Philadelphia Negro, the product of meticulous field work and data gathering in Philadelphia's black Seventh Ward, is commonly classified as sociology and is rightfully hailed as a disciplinedefining study. But Du Bois's sociological analysis, as Aldon Morris acknowledges, was deeply rooted in a historical framing of the black community's development and complexity. ${ }^{13} \mathrm{He}$ continued to embrace a historical approach to the social sciences after moving to Atlanta University and spearheading a series of studies aimed at understanding the "Negro problem" in all of its political, economic, and cultural complexities. ${ }^{14}$

While grounded in scientific methodology, these early works possessed an undeniable political and moral sensibility. Indeed, Du Bois's career as a historian can best be characterized as a

\footnotetext{
${ }^{8}$ W. E. B. Du Bois, The World and Africa: An Inquiry into the Part Which Africa Has Played in World History (New York, 1946; New York, 1965), 80.

${ }^{9}$ W. E. B. Du Bois, The Autobiography of W. E. B. Du Bois: A Soliloquy on Viewing My Life from the Last Decade of Its First Century (New York, 1968), 148.

${ }^{10}$ On the importance of Du Bois's time in Germany and its influence on his intellectual thought, see Lewis, W. E. B. Du Bois, Vol. 1, ch. 6; Kenneth D. Barkin, “Berlin Days,' 1892-1894: W. E. B. Du Bois and German Political Economy” boundary 2 27, no. 3 (Fall 2000): 79-101; Kenneth Barkin, “W. E. B. Du Bois' Love Affair with Imperial Germany," German Studies Review 28, no. 2 (May 2005): 285-302; Robert Gooding-Williams, In the Shadow of Du Bois: Afro-Modern Political Thought in America (Cambridge, MA, 2009); Stephanie J. Shaw, W. E. B. Du Bois and The Souls of Black Folk (Chapel Hill, NC, 2013); and Kwame Anthony Appiah, Lines of Descent: W. E. B. Du Bois and the Emergence of Identity (Cambridge, MA, 2014).

${ }^{11}$ Axel R. Schafer, "W. E. B. Du Bois, German Social Thought, and the Racial Divide in American Progressivism, 1892-1909," Journal of American History 88, no. 3 (Dec. 2001): 925-49.

${ }^{12}$ W. E. B. Du Bois, The Suppression of the African Slave-Trade to the United States of America, 1638-1870, Harvard Historical Studies, No. 1 (New York, 1896).

${ }^{13}$ W. E. B. Du Bois, The Philadelphia Negro: A Social Study (Philadelphia, 1899); Morris recognizes the centrality of Du Bois's historical analysis in The Philadelphia Negro, while still asserting its place "as America's first major empirical sociological study." Aldon D. Morris, The Scholar Denied: W. E. B. Du Bois and the Birth of Modern Sociology (Berkeley, CA, 2015), 45-7; also see Katz and Sugrue, W. E. B. Du Bois, Race, and the City; Robert A. Wortham, ed., W. E. B. Du Bois and the Sociological Imagination: A Reader, 1897-1914 (Waco, TX, 2009).

${ }^{14}$ Elliott M. Rudwick, "W. E. B. Du Bois and the Atlanta University Studies on the Negro," Journal of Negro Education 26, no. 4 (Autumn 1957): 466-76; Earl Wright II, "W. E .B. Du Bois and the Atlanta University Studies on the Negro, Revisited," Journal of African American Studies 9, no. 4 (Mar. 2006): 3-17.
} 
life-long attempt to grapple with the tension between science and imagination, manifested in his dual commitment to truth and to the progress of the race. By the turn of the century, Du Bois painfully came to realize the limitations of a narrow scientific approach to the study of history and the experiences of peoples of African descent. Scholars have given great weight to $\mathrm{Du}$ Bois's self-professed turn away from scientific historicism after the 1899 lynching of Sam Hose and the traumatic news of his knuckles on display in a downtown Atlanta grocery store window. As he described in Dusk of Dawn, the "red ray" of Hose's mutilation awakened Du Bois to the realization that he "could not be a calm, cool, and detached scientist while Negroes were lynched, murdered, and starved." ${ }^{15}$ His establishment of the Niagara Movement in 1905 and the bloody Atlanta Riot the following year further reinforced the futility of disengaged scholarship. Du Bois likewise saw white historians, flagrant in their disregard of scientific objectivity when addressing the history of black people, as complicit in the everyday physical and psychic terror experienced by African Americans. ${ }^{16}$ Troubled by the state of American race relations as well as by the state of American historical study, Du Bois determined to confront and correct both by using the full arsenal of his intellectual and political gifts.

$\mathrm{Du}$ Bois thus began to conjoin his approach to history with a greater sense of art and advocacy, while never fully abandoning the practice of history as a science. Indeed, many of his major publications of the early twentieth century, such as The Souls of Black Folk (1903), John Brown (1909), and The Negro (1915), melded the science of history with the art of historical imagination. Whether in discussing Reconstruction, the history of slave resistance, or the developments of precolonial Africa, Du Bois intended to rescue the history of peoples of African descent from intellectual marginalization-a project that was inextricably bound with his determination to confront the "race problem." ${ }^{\text {"17 }}$ As Charles Wesley, a pioneering black historian in his own right, wrote of Du Bois, "he knew that it was through the mind and pen of the historian that the achievements of persons and peoples were rescued from the dead past, and that the ordinary can become extraordinary through the mind and purpose of the craft of the historian." 18 Du Bois's conscious foregrounding of black achievement and humanity during the "nadir" of American race relations represented a radical act of historical imagination. Without sacrificing his commitment to science, Du Bois viewed history as a weapon to confront the color-line, which he first announced in 1900 as the problem of the twentieth century. ${ }^{19}$ As he mused in the closing chapter of John Brown, "Has John Brown no message-no legacy, then, to the twentieth century? He has and it is this great word: the cost of liberty is less than the price of repression." ${ }^{20}$

This bold reimagining of American history in large part explains why, despite his unparalleled training and intellectual brilliance, Du Bois spent his entire career on the margins of

\footnotetext{
${ }^{15}$ W. E. B. Du Bois, "Dusk of Dawn: An Essay Toward an Autobiography of a Race Concept," in W. E. B. Du Bois: Writings, ed. Nathan Huggins (New York, 1986), 602-3; Eric Porter, The Problem of the Future World: W. E. B. Du Bois and the Race Concept at Midcentury (Durham, NC, 2010), 26.

${ }^{16}$ For example, see John David Smith, "W. E. B. Du Bois and Ulrich Bonnell Phillips: Symbolic Antagonists of the Progressive Era," in Slavery, Race, and American History: Historical Conflict, Trends, and Method, 1866-1953 (London, 1999), 23-32.

${ }^{17}$ Blight, "W. E. B. Du Bois and the Struggle for American Historical Memory." Also see Keith E. Byerman, Seizing the Word: History, Art, and Self in the Work of W. E. B. Du Bois (Athens, GA, 1994).

${ }^{18}$ Charles H. Wesley, “W. E. B. Du Bois-The Historian,” Journal of Negro History 50, no. 3 (July 1965): 147-62, here 161 .

${ }^{19}$ Ira Katznelson, “Du Bois's Century," Social Science History 23, no. 4 (Winter 1999): 459-74; Lewis, W. E. B. Du Bois, Vol. 1, 249-51; Pan-African Association. To the nations of the world, ca. 1900, W. E. B. Du Bois Papers (MS 312), Special Collections and University Archives, University of Massachusetts Amherst Libraries, http://credo. library.umass.edu/view/collection/mums312 (hereafter Du Bois Papers, U-Mass).

${ }^{20}$ W. E. B. Du Bois, John Brown (Philadelphia, 1909), 230. Also see Lawrie Balfour, Democracy's Reconstruction: Thinking Politically with W. E. B. Du Bois (Oxford, 2011), ch. 3.
} 
mainstream academia. He held faculty positions only at black universities, as the historical profession reflected the racially segregated state of American society. ${ }^{21}$ White institutions were also loathe to accommodate the radical revisionism and the challenge to racist dogma that stood as the pillars of Du Bois's historical imagination. This exclusion, however, did not stop Du Bois from continuing to practice the art of history and using the past to inform his understanding of the relationship between race and democracy on a global scale. The Great War would test both his historical vision and moral fortitude.

\section{Du Bois in the World War}

Du Bois began to grapple with the meaning of the world war as soon as hostilities erupted in August 1914. Despite his deep affection for German culture and thought, he quickly sided with the Allied forces, fearing what a victory by Germany and the Central Powers would mean for black people throughout the world. He wrote early and often about the war, presciently analyzing its causes and significance to the global race problem. In the November 1914 issue of The Crisis, the journal of the National Association for the Advancement of Colored People (NAACP), which he operated, Du Bois penned the lengthy editorial "World War and the Color Line," offering his initial musings on the European maelstrom and the place of peoples of African descent in it. He warned his readers against "supposing that the present war is far removed from the color problem of America." Make no mistake, he argued, the war represented "one of the great disasters due to race and color prejudice and it but foreshadows greater disasters in the future." While most observers pointed to the assassination of Archduke Franz Ferdinand, Du Bois asserted that the real cause lay in "the wild quest for Imperial expansion among colored races between Germany, England and France primarily, and Belgium, Italy, Russia and Austria-Hungary in lesser degree." ${ }^{22}$ He provided a fuller articulation of this theory in "The African Roots of War," which appeared in the May 1915 issue of the Atlantic Monthly and has been described by biographer David Levering Lewis as "one of the analytical triumphs of the early twentieth century." ${ }^{23}$ As the bloodshed worsened and showed no signs of abating, Du Bois's writings became even more caustic. "The Great War is the lie unveiled," he wrote following the May 1915 sinking of the Lusitania, viewing the carnage as prime evidence of European civilization's failure and the bankruptcy of the notion of white supremacy. ${ }^{24}$

Woodrow Wilson's April 2, 1917 declaration of war raised the stakes for Du Bois. Wilson famously proclaimed before Congress that the United States had no colonial aspirations and would fight only to make the world "safe for democracy." While fiercely critical of the president's racial policies, Du Bois found inspiration, as did many other progressives, in Wilson's evocative words. Du Bois's historical consciousness shaped his view of the war as a potentially epochal moment that could make the imaginative ideal of democracy a lived reality for African Americans. Leaning on the precedent of the Civil War and other conflicts, he imagined war as an engine of social, political, and economic change with the power to transform the citizenship status of African Americans. In a June 1917 editorial in The Crisis, Du Bois poignantly wrote, "Let us, however, never forget that this country belongs to us even more than to those who lynch, disfranchise, and segregate. As our country it rightly demands our whole-hearted defense as well today as when with Crispus Attucks we fought for independence and with 200,000 black

\footnotetext{
${ }^{21}$ Du Bois taught at Wilberforce University from 1894 to 1896 and at Atlanta University, first from 1897 to 1910 , and returning again from 1934 to 1944 .

22"World War and the Color Line," The Crisis 9, no. 1 (Nov. 1914): 1-52, here 28-30.

${ }^{23}$ W. E. B. Du Bois, “The African Roots of War," Atlantic Monthly (May 1915): 707-14; Lewis, W. E. B. Du Bois, Vol. 1, 503-4.

24"Lusitania," The Crisis 10, no. 2 (June 1915): 53-104, here 81.
} 
soldiers we helped hammer out our own freedom." ${ }^{25}$ Just as they had demonstrated their valor as soldiers in the past, black people would again prove themselves in the current crisis. ${ }^{26}$

Once committed, Du Bois threw himself into the war effort. He stood as arguably the most influential race leader at the time of the war, especially after the 1915 death of his chief rival, Tuskegee Institute president Booker T. Washington. With unrivaled eloquence and political foresight, Du Bois's words and actions encouraging African American loyalty carried great weight. Monthly circulation of The Crisis under his management, and highlighted by his searing editorials, expanded during the war years, surpassing the 100,000 mark in $1919 .{ }^{27}$ His call for patriotic service, from support for a segregated training camp for black officers to the purchasing of war bonds, resonated with African Americans across the country who also grappled with their dual commitments to country and race.

Du Bois's wartime stance, however, cannot be read as mere accommodationism. He continually raised his voice against racial injustice, even as he faced constant surveillance from federal investigators concerned about the potentially subversive content of The Crisis. ${ }^{28}$ At times, he pleaded to the nation's moral conscience, as he did in the editorial "Awake America," written in the devastating aftermath of the July 1917 East St. Louis pogrom, which left well over 100 African American men, women, and children dead, and entire neighborhoods in ashes. "May no blood-smeared garments bind our feet when we rise to make the world safe for democracy ... Awake!," he cried. "Put on they strength, America-put on thy beautiful robes. Become not a bye word and jest among the nations by the hypocrisy of your word and contradiction of your deeds." ${ }^{29}$ Eschewing gentle persuasion, he directly challenged the racial policies of the federal government and the War Department, especially concerning the treatment of African American soldiers and officers. "It seems to be necessary to insist upon justice toward the Negro from the War Department," he wrote in the May 1918 number of The Crisis. He prefaced a list of concerns and demands by stating that "intentional injustice toward colored soldiers is the poorest investment that this nation can make just now."30

In some cases, Du Bois seethed with anger and righteous indignation. In the January 1918 issue of The Crisis, he penned the editorial "Thirteen," dedicated to the memory of the thirteen black soldiers of the 24th Infantry executed without due process for their role in the August 24, 1917 Houston rebellion. "They have gone to their death," he lamented. "Thirteen young, strong men; soldiers who have fought for a country which never was wholly theirs; men born to suffer ridicule, injustice, and at last, death itself." Du Bois conceded that if tried and legally found guilty, the soldiers deserved punishment. But he also insisted:

... we can protest and we do protest against the shameful treatment which these men and which we, their brothers, receive all our lives, and which our fathers received, and our children await; and above all we raise our clenched hands against the hundreds of thousands of white murderers, rapists, and scoundrels who have oppressed, killed, ruined, robbed, and debased their black fellow men and fellow women, and yet, today, walk scot-free, un-whipped of justice, uncondemned by millions of their white fellow citizens, and unrebuked by the President of the United States. ${ }^{31}$

\footnotetext{
25“Resolutions of the Washington Conference," The Crisis 14, no. 1 (June 1917): 53-104, here 59.

${ }^{26}$ For historical perspective on African American views on war and military service, see A Yęmisi Jimoh and Françoise Hamlin, eds., These Truly Are the Brave: An Anthology of African American Writings on War and Citizenship (Gainesville, FL, 2015).

${ }^{27}$ Lewis, W. E. B. Du Bois, Vol. 1, 544; Lewis, W. E. B. Du Bois, Vol. 2, 2-4.

${ }^{28}$ On surveillance of The Crisis, see Ellis, Race, War and Surveillance and Kornweibel, Jr., "Investigate Everything."

${ }^{29}$ W. E. B. Du Bois, “Awake America,” The Crisis 14, no. 5 (Sept. 1917): 209-60, here 216.

${ }^{30}$ W. E. B. Du Bois, "The Negro and the War Department," The Crisis 16, no. 1 (May 1918): 1-52, here 7-8.

${ }^{31}$ W. E. B. Du Bois, “Thirteen,” The Crisis 15, no. 5 (Jan. 1918): 105-56, here 114. For details and analysis of the Houston rebellion, see Robert V. Haynes, A Night of Violence: The Houston Riot of 1917 (Baton Rouge, LA, 1976);
} 
When confronted with gross injustice, Du Bois fearlessly excoriated white Americans for their hypocrisy.

Nevertheless, Du Bois's wartime militancy has been overshadowed in historical memory by his efforts, in cooperation with former NAACP chairman and close friend Joel Spingarn, to secure a captaincy in the War Department's Military Intelligence Division (MID), as well as by the accompanying "Close Ranks" editorial he wrote for the July 1918 issue of The Crisis. ${ }^{32}$ "Let us, while this war lasts, forget our special grievances and close our ranks shoulder to shoulder with our own white fellow citizens and the allied nations that are fighting for democracy," Du Bois declared. "We make no ordinary sacrifice, but we make it gladly and willingly with our eyes lifted to the hills." ${ }^{33}$ The editorial unleashed a torrent of criticism in the black press and beyond about Du Bois's integrity, along with a furious debate about the relationship between patriotism and protest. Long-time ally William Monroe Trotter branded Du Bois "a rank quitter" in the fight for equal rights. "Du Bois is regarded much in the same way as a knight in the middle ages who had had his armor stripped from him, his arms reversed and his spurs hacked off," mocked the Harlem socialist Hubert Harrison. "Democracy will not obtain in America, to say the least of the world, if we neglect the principle for which we fight," Joseph Glenn, a black resident of Chicago, scolded Du Bois. "Duty and justice go hand in hand." ${ }^{34}$ For Du Bois, who had committed his life to fighting for black people, no charge could be more painful than being labeled a traitor to the race. Although military intelligence officials rejected Du Bois's application for the commission and he quickly attempted to put the controversy behind him, the damage to Du Bois's reputation as a radical voice in the fight for equal rights had been done. The "Close Ranks" uproar haunted him well into the later years of his life. ${ }^{35}$

$\mathrm{Du}$ Bois's attempt to strike a grand bargain with the federal government and American democracy seemed yet more misguided in light of the U.S. military's treatment of black servicemen. Approximately 380,000 African American soldiers served in the racially segregated United States army. The majority of black troops in France unglamorously labored in the Services of Supply, loading and unloading ships, digging ditches, laying railroad tracks, cleaning latrines, and burying the dead. The army reluctantly agreed to the creation of two black combat units, the 92nd Division, composed of draftees, and the 93rd Division, made up largely of black national guardsmen. While the 93rd Division compiled a stellar combat record, the 92nd Division became, as Du Bois later described it, "the storm center of the Negro troops."36 Racist white commanders and deliberate neglect from the War Department doomed the performance of the division from the start, while its black officers, Du Bois's shining examples of "Talented Tenth" manhood and racial leadership, endured humiliation after humiliation. African Americans could point to several notable battlefield triumphs and moments of racial

Lentz-Smith, Freedom Struggles; Tyina L. Steptoe, Houston Bound: Culture and Color in a Jim Crow City (Berkeley, CA, 2015), 31-5; and Williams, Torchbearers of Democracy.

${ }^{32}$ Mark Ellis and David Levering Lewis argue, convincingly, that Du Bois wrote "Close Ranks" to alleviate concern within the Military Intelligence Division about the tone of The Crisis and induce a favorable decision regarding his application for a captaincy commission. See Ellis, "Closing Ranks' and 'Seeking Honors" and Lewis, W. E. B. Du Bois, Vol. 1, 552-560. William Jordan, in contrast, argues that "Close Ranks" and the commission were unrelated, with the editorial being consistent with Du Bois's wartime accommodationism; see Jordan, "The Damnable Dilemma."

${ }^{33}$ W. E. B. Du Bois, “Close Ranks," The Crisis 16, no. 3 (July 1918): 105-56, here 111.

34"DuBois, One-Time Radical Leader, Deserts and Betrays Cause of His Race," Richmond Planet, Aug. 3, 1918, 1; Hubert Harrison, "The Descent of Dr. Du Bois," in A Hubert Harrison Reader, ed. Jeffrey B. Perry (Middletown, CT, 2001), 170-3; Joseph O. Glenn to The Crisis, July 25, 1918, Du Bois Papers, U-Mass.

${ }^{35}$ Ellis, "'Closing Ranks' and 'Seeking Honors,"” 113-8; Lewis, W. E. B. Du Bois, Vol. I, 559-60; Du Bois, The Autobiography of W. E. B. Du Bois, 274; "Dusk of Dawn" in W. E. B. Du Bois: Writings, 740-1.

${ }^{36}$ W. E. B. Du Bois, “An Essay Toward a History of the Black Man in the Great War," The Crisis 18, no. 2 (June 1919): 53-120, here 63-87. 
pride. But for most black soldiers, the war for democracy that Du Bois had so enthusiastically championed devolved into a personal hell. ${ }^{37}$

$\mathrm{Du}$ Bois was by no means the only historian struggling with his relationship to the American war effort. The global crisis elicited a simultaneous crisis in the historical profession. Many scholars abandoned their once dogged commitment to objectivity in place of patriotic support for the Allied cause and condemnation of Germany. Leading professors, who had roundly denounced their German counterparts for eschewing academic standards for propaganda, hypocritically adopted the same approach when the United States entered the war. The pro-war writings of American historians, from their perspective, would serve the noble cause of preserving democracy, unlike the supposed totalitarian aims of German scholars. Most attempted to walk the fine line between reputable scholarship and blatant propaganda. Several notable historians, however, unabashedly threw themselves into the war effort. Du Bois's Harvard mentor Albert Bushnell Hart stood at the forefront of this group, serving as a prominent member of the hyper-nationalist American Security League and producing several pieces of pro-Allied literature. $^{38}$

With the war nearing conclusion and his political standing on shaky ground, Du Bois returned to the solace of scholarship in an attempt to make sense of the maelstrom and his connection to it. At the October 1918 meeting of the NAACP Board of Directors, Treasurer and frequent nemesis Oswald Garrison Villard recommended that the group move quickly "to compile records concerning the Negro soldier's work in the present war," with the goal of "getting out a book" by the war's conclusion. Du Bois eagerly accepted the challenge. ${ }^{39}$ Here was an exciting scholarly endeavor that could simultaneously repair his sullied reputation. Du Bois initially attempted to forge partnerships with Carter G. Woodson, fellow Harvard history doctorate and founder of the Association for the Study of Negro Life and History, and Emmett J. Scott, the influential former secretary to Booker T. Washington at Tuskegee who served as special assistant to Secretary of War Newton D. Baker on matters related to African Americans. But clashing egos and competing agendas ultimately prevented what might have been an impressive collaborative effort. ${ }^{40}$ Forging ahead alone, Du Bois sailed to France on December 1, 1918, as part of the official press delegation accompanying president Woodrow Wilson to the Paris Peace Conference. During his roughly three months in France, Du Bois not only organized the landmark Pan-African Congress of February 1919, but also conducted research for his NAACP war history, which required visiting the battlefields, collecting documents, and, most important, speaking directly with African American servicemen. ${ }^{41}$

$\mathrm{Du}$ Bois would never forget the searing testimonies he heard and read from these African American soldiers and officers. "We had no privileges and were same as prisoners," Sergeant Louis Pontlock of the 92nd Division recalled of his treatment at the hands of white

\footnotetext{
${ }^{37}$ See Barbeau and Henri, The Unknown Soldiers; Lentz-Smith, Freedom Struggles; and Williams, Torchbearers of Democracy.

${ }^{38}$ Peter Novick, That Noble Dream: The "Objectivity Question" and the American Historical Profession (Cambridge, MA, 1988); Selig Adler, "The War-Guilt Question and American Disillusionment, 1918-1928," Journal of Modern History 23, no. 1 (Mar. 1951), 1-28, here 1-2. For an example of pro-Allied historical literature, see Albert Bushnell Hart and Arthur O. Lovejoy, eds., Handbook of the War for Readers, Speakers and Teachers (New York, 1918).

${ }^{39}$ Minutes of Board Meeting, Oct. 14, 1918, Du Bois Papers, U-Mass.

${ }^{40} \mathrm{Du}$ Bois's negotiations with both men collapsed as Woodson demanded full editorial control and Scott moved forward with plans to publish a book of his own. See Black Man and the Wounded World, Proposed Editorial Board, Scott, Emmett J., 1918-1919, folder 30, box 14, W. E. B. Du Bois Collection, Special Collections and Archives, Fisk University (hereafter Du Bois Collection, Fisk); Black Man and the Wounded World, Proposed Editorial Board, Wood, C. Hollingsworth-Woodson, Carter G., 1918, N.D., folder 32, box 14, Du Bois Collection, Fisk.

${ }^{41}$ Lewis, W. E. B. Du Bois, Vol. 1, 561-78.
} 
officers. "We were considered as thieves, 'cut throats' and sexual maniacs." Captain Virgil Boutte, an officer in the 92nd Division and a close friend of Du Bois, came away from his battles against racism in the American army convinced that, "No nation on earth has ever hated a group as the Americans hate Negroes." 42 The war and American white supremacy had left black soldiers deeply embittered.

"Never in my life have I heard such an astounding series of stories," Du Bois wrote from France in a January 1919 letter to NAACP colleagues. "You have not the faintest conception of what these men have been through. It is not only astonishing but it will arouse every ounce of sympathetic blood in your veins." ${ }^{43}$ His interviews uncovered how overseas racism acted as a form of war-induced trauma for black servicemen that was as physically and emotionally painful, disruptive, and confusing as the "shell shock" experienced by other World War I participants. ${ }^{44}$ Just as medical doctors struggled to treat the hidden wounds of shell shock, Du Bois saw it as his responsibility to treat the traumatic effects of racism by coming to the defense of African American soldiers through the writing of history.

\section{Writing the "History" of the Black Experience in the World War}

As editor of The Crisis, Du Bois had a powerful platform to broadcast what he had seen and experienced in France, as well as to begin to historicize the meanings of black participation in the war. The postwar issues of The Crisis are a remarkable repository of Du Bois's writings on the subject, combining both history and memoir. ${ }^{45}$ In moving prose, he embraced his own role in this watershed moment for the modern world, recounting his experiences touring the Western Front's devastated battlefields, the marvelous sight of African colonial troops being honored by the French military, his enchantment with the colorblind kindheartedness of his French hosts, and the triumph of the 1919 Pan-African Congress. ${ }^{46} \mathrm{He}$ also whetted the appetite of readers for the envisioned war history in the March 1919 issue of The Crisis with a brief précis titled "The Black Man in the Revolution of 1914-1918." Intended as a preliminary outline of the larger history, Du Bois felt confident in sharing his initial interpretations of the experiences of black soldiers and the meaning of the war. "The black soldier saved civilization in 1914-18," he asserted. Despite virulent racism, African American soldiers and officers had left a record of which the race could be proud. Du Bois predicted that, despite this, "the American army is going to return to America determined to disparage the black officer and eliminate him from the army despite his record." ${ }^{27} \mathrm{He}$ insisted that African Americans, with history as their weapon, must not allow this to happen.

Du Bois used the May 1919 issue of The Crisis to offer a passionate, wide-ranging assessment of the treatment of African American soldiers and the larger significance of the war to the future of the race. He informed readers about his "mission" in France, debunked false charges of rape levied against black troops, and, in the "Documents of War" section, revealed an explosive memo from the American High Command informing French officers on the nature of the American "race question" and instructing them to avoid "spoiling" black soldiers with any "public

\footnotetext{
${ }^{42}$ Louis Pontlock to W. E. B. Du Bois, Apr. 26, 1919, Du Bois Papers, U-Mass.

${ }^{43}$ W. E. B. Du Bois to NAACP Board, Jan. 12, 1919, folder 2, Box I: C385, NAACP Papers, Part I, Manuscript Division, Library of Congress, Washington, DC.

${ }^{44}$ See Gregory M. Thomas, Treating the Trauma of the Great War: Soldiers, Civilians, and Psychiatry in France, 1914-1940 (Baton Rouge, LA, 2009), 9.

${ }^{45}$ Smith, "The Crisis in the Great War."

46"Vive La France!" The Crisis 15, no. 5 (Mar. 1918): 209-60, here 215; "For What?," "The Fields of Battle," "Pan-African Congress," The Crisis 15, no. 6 (Apr. 1919): 261-312, here 268-9, 271-4. Du Bois of course was not alone in recognizing this as a watershed moment in global history. See Erez Manela, The Wilsonian Moment: Self-Determination and the International Origins of Anticolonial Nationalism (Oxford, UK, 2007).

47“The Black Man in the Revolution of 1914-1918," The Crisis 17, no. 5 (Mar. 1919): 209-60, here 218-23.
} 
expression of intimacy." The highlight, however, was "Returning Soldiers," Du Bois's second most well-known editorial after "Close Ranks." Going a long way toward resuscitating his reputation, Du Bois emphatically declared that he and all other "Soldiers of Democracy" had returned from France and now confronted the aftermath of the war prepared to "fight a sterner, longer, more unbending battle against the forces of hell in our own land." His words would serve as a rallying cry for African Americans in the aftermath of the war: "We return. We return from fighting. We return fighting." 48 Federal postal officials, so unnerved by the tone and content of the issue, withheld its distribution for six days until relenting to public pressure. ${ }^{49}$

The postwar struggle for democracy, in Du Bois's eyes, had to include a bold reclamation of history. "Most American Negroes," he wrote in an editorial announcing his plans to produce a study of the black experience in the war, "do not realize that the imperative duty of the moment is to fix in history the status of our Negro troops." Racist white military and government officials had already begun to prepare "a fatal attack" on the reputation of African American troops by labeling black officers as cowards and failures. "This is not true," Du Bois asserted, "and the facts exist to disprove it, but they must be marshaled with historical vision and scientific accuracy." ${ }^{50} \mathrm{Du}$ Bois intended to pair a scientific approach to history with the tools of own historical imagination to wage a preemptive strike against attempts to distort and marginalize African Americans in the history and memory of the war.

His most comprehensive attempt to do this appeared in June 1919, in "An Essay Toward a History of the Black Man in the Great War," Du Bois's most detailed published scholarship on African American military participation in the conflict and black soldiers' contributions to the Allied victory. It was, he conceded, only "a first attempt at the story of the Hell which war in the fateful years of 1914-1919 meant to Black Folk, and particularly to American Negroes." Recognizing, as a scientifically trained historian, the inherent challenges he faced in writing about such a recent subject-and one in which he himself had controversially participated, he nevertheless felt a profound sense of urgency to begin documenting and analyzing it. Using the copious research he had gathered while overseas, Du Bois asserted that African American servicemen, as laborers and combatants, played a vital role in the war even as they suffered from the racist hatred of their fellow white Americans, in stark contrast to the colorblind embrace they received from the French. Though his early work may have been "only an attempt, full of the mistakes which nearness to the scene and many necessarily missing facts, such as only time can supply, combine to foil in part," and though "written now in the heat of strong memories and in the place of skulls," it possessed a "truth which cold delay can never alter or bring back." ${ }^{51}$ Supremely confident in his intellectual abilities, Du Bois believed that historical "truth," marshalled by his pen, could effectively withstand the "heat of strong memories" and overcome "cold delay." As the battle over the memory and legacy of black soldiers loomed, African Americans, in Du Bois's view, had the power of history on their side.

$\mathrm{Du}$ Bois, quite consciously, positioned himself as African American veterans' historical muse. In the May edition of The Crisis, Du Bois encouraged black soldiers and officers "to see that the Editor of The Crisis receives documents, diaries and information such as will enable The Crisis history of the war to be complete, true and unanswerable." 52 The immediate response was remarkable, as returned black soldiers flooded the office of The Crisis with letters, diaries, official military documents, and personal memoirs. Most of the letters expressed a clear

\footnotetext{
48"My Mission," "Rape," "Documents of War," "Returning Soldiers," The Crisis 18, no. 1 (May 1919): 1-51, here 7-21; Lewis, W. E. B. Du Bois, Vol. 1, 578.

${ }^{49}$ See Theodore Kornweibel, Jr., "Seeing Red": Federal Campaigns against Black Militancy, 1919-1925 (Bloomington, IN, 1998), 54-75.

50"History," The Crisis 18, no. 1 (May 1919), 1-51, here 11.

${ }^{51}$ W. E. B. Du Bois, "An Essay Toward a History of the Black Man in the Great War," The Crisis 18, no. 2 (June 1919): 53-118, here 63-87.

52“History," The Crisis (May 1919): 11; “Documents of War," The Crisis (May 1919): 21.
} 
interest in the war history. Many veterans used the opportunity to correspond with Du Bois to vent their anger, reflecting a deep collective trauma and desire to be healed through an accurate historical representation of their experience. Sergeant Charles Isum of the 92nd Division, for example, expressed pleasure that "someone has the nerve and backbone to tell the public the unvarnished facts concerning the injustice, discrimination and southern prejudice practices by the white Americans against the black Americans in France." ${ }^{53}$ Reading letter after pained letter, Du Bois could not help but to internalize their anguish and aspirations. The deluge of documents from black veterans constituted the bulk of Du Bois's research materials for the war history. Brimming with optimism and buoyed by the jubilant return of black soldiers throughout the country, Du Bois expected the book, initially titled The Negro in the Revolution of the Twentieth Century, to appear by October 1919. ${ }^{54}$

During the summer of 1919, just as he began to work on the book, the "red ray" of racial violence again struck Du Bois. During what James Weldon Johnson dubbed the "Red Summer," race riots and full scale massacres exploded across the country. The number of southern lynchings skyrocketed. Returned black servicemen found themselves fighting for their lives. Violent racial unrest erupted outside of the United States as well. ${ }^{55}$ The horror of that summer, the bloody apogee of a year Du Bois would remember as one of "extraordinary and unexpected reaction," was seared onto his memory. ${ }^{56}$ To his great shock, instead of opening new democratic opportunities for African Americans and other peoples of African descent, the war had made global race relations even worse.

$\mathrm{Du}$ Bois channeled his immediate postwar disillusionment into the 1920 book Darkwater. Darkwater, promoted at the time as a sequel to The Souls of Black Folk, was more accurately an attempt by $\mathrm{Du}$ Bois to make sense of the confusion of the war and its aftermath. ${ }^{57}$ Indeed, the war and its reverberations-domestic and global, social and economic, personal and collective-constitutes the central theme of the book. "I believe in the Prince of Peace. I believe that War is Murder," Du Bois reaffirmed with new contextual significance in the opening "Credo." 58 In the chapter "The Souls of White Folk," originally published as an essay in 1910 but revised for the 1920 volume, Du Bois now wrote, "Let me say this again and emphasize it and leave no room for mistaken meaning: The World War was primarily the jealous and

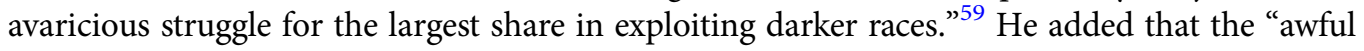
cataclysm" had revealed the bankruptcy of whiteness and the emptiness of European civilization. "This is not Europe gone mad," Du Bois claimed, "this is not aberration nor insanity; this is Europe; this seeming Terrible is the real soul of white culture-back of all culture,-stripped and visible today." ${ }^{60} \mathrm{He}$ additionally attacked the hypocrisy of the United States for positioning

\footnotetext{
${ }^{53}$ Charles R. Isum to W. E. B. Du Bois, May 17, 1919, Du Bois Papers, U-Mass.

54"The History of the Great War," The Crisis (June 1919): 59-60.

${ }^{55}$ Key works on the "Red Summer" include David F. Krugler, 1919, The Year of Racial Violence: How African Americans Fought Back (Cambridge, UK, 2014); Cameron McWhirter, Red Summer: The Summer of 1919 and the Awakening of Black America (New York, 2011); and William M. Tuttle, Jr., Race Riot: Chicago in the Red Summer of 1919 (New York, 1970). For examples of global racial unrest in 1919, see Peter Freyer, Staying Power: The History of Black People in Britain (London, 1985); Kelvin Singh, Race and Class Struggles in a Colonial State: Trinidad, 1919-1945 (Kingston, Jamaica, 1994); Tyler Stovall, "The Color Line behind the Lines: Racial Violence in France during the Great War," The American Historical Review 103, no. 3 (June 1998): 73769; Winston James, Holding Aloft the Banner of Ethiopia: Caribbean Radicalism in Early Twentieth-Century America (London, 1999); Jacqueline Jenkinson, Black 1919: Riots, Racism and Resistance in Imperial Britain (Liverpool, UK, 2009); and Nicholas Lloyd, The Amritsar Massacre: The Untold Story of One Fateful Day (London, 2011).

${ }^{56}$ Du Bois, Dusk of Dawn in W. E. B. Du Bois: Writings, 747.

${ }^{57}$ Lewis, W. E. B. Du Bois, Vol. 2, 13. Also see Evelyn Brooks Higginbotham, “Introduction," in W. E. B. Du Bois, Darkwater: Voices from Within the Veil (Oxford, 2014), xxv-xxxix.

${ }^{58}$ W. E. B. Du Bois, Darkwater: Voices from Within the Veil (New York, 1920; Mineola, NY, 1999$), 1$.

${ }^{59}$ Ibid., 28.

${ }^{60}$ Ibid., 22.
} 
itself as a "natural peacemaker" and "moral protagonist" in the wake of the war. "No nation is less fitted for this role," he charged. "Instead of standing as a great example of the success of democracy and the possibility of human brotherhood America has taken her place as an awful example of its pitfall and failures, so far as black and brown and yellow peoples are concerned." $\mathrm{Du}$ Bois predicted that so long as the exploitation of peoples of African descent continued, "then this is not the end of world war,-it is but the beginning."

\section{The Black Man and the Wounded World}

Du Bois declared in Darkwater, published only three years after the United States had entered the war, that "Most Americans have forgotten the extraordinary series of events which worked the feelings of black America to fever heat." ${ }^{62} \mathrm{Du}$ Bois thus re-committed to the war history project. With African Americans and black veterans waiting anxiously, Du Bois hoped to find the time and resources to complete the book. He devoted significant effort between 1920 and 1922 to drafting multiple chapters. Even though self-imposed deadlines came and went, the contours of a truly unique book nevertheless began to take shape. These early drafts reflected an attempt by $\mathrm{Du}$ Bois to find redemptive value in the war by reclaiming the historical legacy of black soldiers through a meticulous study of their experience. To this end, he composed chapters about the black labor troops and various regiments of the 92nd and 93rd Divisions, densely packed with documents and first-hand testimonies. With nothing less than the historical reputation of the race at stake, the evidence proving that African Americans made a meaningful contribution to the war despite unrelenting discrimination had to be irrefutable. ${ }^{63}$

But Du Bois's scientific approach to the history of the war was not without obstacles, the most vexing being $\mathrm{Du}$ Bois himself. He also approached the book as an opportunity to find redemption from his controversial support for the war. A chapter he drafted titled "The Challenge" summarized the difficult choices African Americans faced in placing their faith with America and the Allies. ${ }^{64}$ The final paragraph, never published, represented one of Du Bois's most dramatic reflections on black participation in the war and his own conflicted personal memories:

It will thus be seen how difficult a period the Negro passed through. For a moment-and it was but a moment, it passed, but for a moment the country seemed to rise to its mightiest stature. I saw it and saw it with streaming eyes. I have been called bitter. I am bitter but here I saw all the hurts, the tears, the pain as in one country and that country was mine. The moment passed and is gone, but thank God that it came once. The war that brought slavery to most men (and indeed in the end to us) thus brought to some of us at a time a new vision of freedom. We were at least free from our bonds. The inhibitions fell away. We could think with the nation and not as a mere group. We could rise to mighty selfishness. The nation, our country, the allies as champions of the little hurt folk, democracy. We were mad with the new vision. We did not examine the ideal too narrowly. Even if it was false it was good to rise from murky, long, sheathing waters and breathe air and see through lifting mist "the stars, the old and everlasting stars." How simple the problem was after all

\footnotetext{
${ }^{61}$ Ibid., 28.

${ }^{62}$ Ibid., 130.

${ }^{63}$ The Black Man and the Wounded World (unpublished), chs. 10, 13, 14, 16, folders 6-10, box 27, Du Bois Collection, Fisk. Keene argues that Du Bois, in his effort to defend the record of African American soldiers, elevated them to the level of racial symbols, in the process reducing their human complexity. Keene, "W. E. B. Du Bois and the Wounded World," 141-2.

${ }^{64}$ Keene, "W. E. B. Du Bois and the Wounded World," 139-40; The Black Man and the Wounded World (unpublished), ch. 8 "The Challenge," folder 5, box 27, Du Bois Collection, Fisk.
} 
with the main trend right? With the great ideal set, what mattered the exceptions, the little evil facts? The edges of our inner dark world slipped and sought to coalesce with the surrounding half known larger world. Great movements were our movements. Great joys and sorrows ours. We had no longer the problem to resist thought and scowl as they smile and laugh as they cried. We were mad-that is the only word for it, we were mad and let it not excuse us to say that the madness was divine. It was insanity just the same. The primal beast was out to kill with prongs. How in the end did all this set with our inner problem? After all it was not a mere bargain-it was a moving wish. ${ }^{65}$

The passage, on the surface, echoes Du Bois's attempts in The Crisis and elsewhere to justify the "Close Ranks" editorial and his support for the war. But it goes further and much deeper. We are exposed to a Du Bois who is torn, confused, and grasping for answers. The war caused $\mathrm{Du}$ Bois to wrestle with his identity in a way that no other historical moment had. In his 1897 essay "The Conservation of Races," Du Bois asked, "What, after all am I? Am I an American or am I a Negro? Can I be both? Or is it my duty to cease to be a Negro as soon as possible and be an American?" ${ }^{66}$ In Du Bois's mind, the war had answered these questions. He was an American. In the coercive crucible of propaganda and hyper-patriotism, the two "warring ideals" of being black and being American that Du Bois so eloquently articulated in The Souls of Black Folk had for the moment been reconciled. However temporary and fleeting, the "new vision of freedom" offered by the war allowed African Americans to imagine themselves as part of the larger nation. The existential joy he experienced in the heat of battle by being able to set aside "the evil little facts" and "coalesce with the surrounding half known larger world" was personally fulfilling, even emancipatory. But the costs had been high. As he admitted, the "new vision" and ideal of democracy proved illusory. He and the race were left with bitterness and disappointment. All $\mathrm{Du}$ Bois could do in trying to rationalize his feelings was to plead temporary insanity. The world had gone mad, and Du Bois along with it. He thus tried to escape personal culpability for his actions and the sincere, yet ultimately foolish, decision to place his faith in both the United States and its democracy. While he may have intended for the closing passage of his chapter to project confidence to readers, it instead revealed an attempt by Du Bois to convince himself, unsuccessfully, that his wartime stance had been worthwhile.

$\mathrm{Du}$ Bois believed his definitive study of the black experience in the war would offer final vindication. But despite frequent promises, in public and private, that the book was forthcoming, it remained far from finished. He held out hope that even with his numerous other commitments-future book projects, editorials for The Crisis, speaking engagements, pan-African congresses-and a lack of financial support, it would somehow soon be completed. ${ }^{67}$ However, the worsening of conditions facing African Americans and other peoples of African descent, combined with personal tragedies, continued to intercede. The walls of caste segregation grew higher; racial violence became more horrific; the grip of Europe on Africa tightened. On a personal level, the January 1922 death of his close friend colonel Charles Young came as an especially harsh blow. Young, the highest ranking black officer in the army, was unjustly retired from active service during the war for dubious health reasons to prevent him from becoming a general. The army reinstated him after the armistice and assigned him to Liberia. ${ }^{68}$ In a July 1923 elegy devoted to Charles Young, Du Bois accused the government of an "inexcusable crime" by sending him there. "For, if Charles Young's blood pressure was too high for him to go to France," he wrote, "why was it not too high

\footnotetext{
${ }^{65}$ Ibid.

66“"The Conservation of Races," in W. E. B. Du Bois: Writings, 821.

${ }^{67}$ Lewis, W. E. B. Du Bois, Vol. 2, 28-9.

${ }^{68}$ On Charles Young, see David P. Kilroy, For Race and Country: The Life and Career of Colonel Charles Young (Westport, CT, 2003) and Brian Shellum, Black Officer in a Buffalo Soldier Regiment: The Military Career of Charles Young (Lincoln, NE, 2010).
} 
for him to be sent to the even more arduous duty in the swamps of West Africa?" "God rest his sickened soul," Du Bois ended, "but give our souls no rest if we let the truth concerning him droop, overlaid with lies." ${ }^{69}$ Du Bois's disillusionment with the war increased day by day, yet he owed it to the memory of Charles Young and the thousands of other black soldiers he had encouraged to spill blood for the cause of democracy to complete his book, tell the truth, debunk the lies, defend their honor, and set the historical record straight.

As he pressed on, Du Bois's assessment of the war shifted dramatically. He continued to envision his book as a reclamation of the manhood of black soldiers and officers, and through them the race as a whole. However, he could no longer ignore his doubts about the meaning of their sacrifice. His initial conceptualization of the conflict as a revolutionary moment with the potential for the reconstruction of global democracy and race relations gave way to an interpretation of it as one of the darkest moments in modern world history. He had drafted several chapters on the impact of the war on the African diaspora, including one that mused on the development of a "black world" and what its existence might portend for the future of the race. ${ }^{70}$ But the postwar condition of peoples of African descent slowly dashed his optimism. Initially inspired by a pan-African movement that would "center the attention of the world in another half century," now he grew more skeptical, as his congresses of 1919, 1921, and 1923, while symbolically meaningful, yielded at the time few tangible results. ${ }^{71}$ Immediately after the war, Du Bois had dreamed of a unified black world marching toward freedom and democracy. Now this world seemed irrevocably damaged. The title of his book, originally The Negro in the Revolution of the Twentieth Century, became by 1923 The Black Man and the Wounded World.

$\mathrm{Du}$ Bois's followers received their first taste of the long-delayed study when he published the opening chapter, "Interpretations," in the January 1924 issue of The Crisis under the title "The Black Man and the Wounded World: A History of the Negro Race in the World War and After." The chapter revealed the continued influence of the German school of historical economics on Du Bois, as well as a sharpened moral critique of global capitalism. He characterized the modern world as ruled by the "Dominant Wills," a narrow class of income seekers who by means of wealth, propaganda, manipulation of law, and physical force subverted the only natural challenge to their power: democracy. As wage earners, through industrial unionism, threatened the rule of the Dominant Wills in the late nineteenth century, a "New Imperialism" based on "the policy of conquest, slavery, monopoly and theft in Eastern Europe, Asia, Africa, and Central and South America" emerged as a more profitable political and economic system. Race propaganda and the "false scientific dogma" of white supremacy provided the ideological underpinning for this new system, which became so effective that white men of all classes believed that "the advancement of civilization necessarily involves slavery, lust and rapine in Africa." Blame for the war, therefore, lay not with nations, but with the men who led them and those who followed their lead: "Not Germany but certain Germans. Not England but certain Englishmen. Not France but certain Frenchmen. All those modern civilized citizens who submitted voluntarily to the Dominant Wills of those who rule the leading lands in 1914 were blood guilty of the murder of the men who fell in the war." "Individuals caused the Great War," he proclaimed, "did its deviltry and are guilty of its endless Crime." Du Bois sought not just historical explanation, but accountability as well. He therefore minced no words in expressing his opinion of the war's legacy, describing it as "a Scourge, an Evil, a retrogression to Barbarism, a waste, a wholesale murder." 72

\footnotetext{
${ }^{69}$ Du Bois, "Charles Young," The Crisis 26, no. 3 (July 1923): 98-144, here 104-6.

${ }^{70}$ The Black Man and the Wounded World (unpublished), ch. 3, “The World of Black Folk," folder 24, box 27; ch. 4 "Black France"; ch. 5, "Black England," folders 1-2, box 28, Du Bois Collection, Fisk. For further discussion, see Keene, "W. E. B. Du Bois and the Wounded World," 143-7.

${ }^{71}$ The Black Man and the Wounded World (unpublished), ch. 3, "The World of Black Folk," folder 24, box 27, Du Bois Collection, Fisk.

${ }^{72}$ W. E. B. Du Bois, "The Black Man and the Wounded World: A History of the Negro Race in the World War and After," The Crisis 27, no. 3 (Jan. 1924): 98-146, here 110-14; Lewis, W. E. B. Du Bois, Vol. 2, 254.
} 
As this powerful opening chapter of The Black Man and the Wounded World reflected, Du Bois now saw tragedy as the war's central theme. The war, he thought, was tragic not solely because of the incredible loss of life and incomprehensible physical destruction, but also because it had strengthened white supremacy across the globe. It had redoubled the economic exploitation of peoples of African descent by the American and European ruling classes, bought with the silent complicity of white wage earners and the perversion of democracy. It was a war that sustained the power of the few at the expense of the many.

This daring perspective accounts in large part for why Du Bois experienced such difficulty in obtaining support to complete the book. Throughout the 1920s and early 1930s, he sent inquires to several major publishing houses and philanthropic organizations-the Macmillan Company, the Slater Fund, the Guggenheim Foundation, American Fund for Public Service, and the Julius Rosenwald Fund. Each expressed courteous interest but ultimately offered regrets. ${ }^{73}$ Publishers and foundations alike interpreted the American public's disillusionment with the war as a clear sign that books on its history had a limited market. In 1924, Carter G. Woodson, as he considered publishing the book, even told Du Bois that "enthusiasm of the World War is about as dead as the League of Nations" and that "Negroes themselves have lost interest in their own record during that upheaval." ${ }^{\text {74 }}$ But books by prominent white historians and memoirs by former generals, like John Pershing, were deemed a worthy investment and garnered significant public and scholarly attention. Publishers and foundations hesitated to support Du Bois because he promised a book that would explicitly center the black experience in the war, radically recast its focus, and likely incite controversy by challenging prevailing historical assumptions. In a September 1927 letter to James H. Dillard, regarding possible financial assistance from the Slater Fund, Du Bois accepted this reality:

Of course, any history must contain controversial matter. I mean by that, history is an interpretation of facts and must, of course, be a question as to whether the interpretation is justified by the facts. But scientific history tries to present all the facts and to make other facts available by careful reference. This is what I shall certainly do in the history of the Negro troops. ${ }^{75}$

Stymied by the lack of traditional financial support for the book, Du Bois sought creative ways of bringing it to the public. His introductory preview published in January 1924 concluded with the following statement and request:

On account of its length and its frankly pro-Negro attitude, it is possible that Dr. Du Bois' history of the Negro in the World War will have to be published by subscription. In this case the possibility of publication will depend on the number of persons willing to subscribe. If you are interested will you sign and return the appended blank or one similar to it? ${ }^{76}$

He immediately received over 100 pledges and inquiries for further information, with black veterans, many still eager to have their story told, expressing strong interest. ${ }^{77}$ Encouraged by the enthusiastic response, Du Bois continued working on the book and published part of Chapter Two, "The Story of the War," which recalled the pivotal historical events of 1914 and 1915, in

\footnotetext{
${ }^{73}$ W. E. B. Du Bois to the Macmillan Company, Sept. 10, 1925; J. H. Dillard to W. E. B. Du Bois, June 25, 1927; W. E. B. Du Bois to John Simon Guggenheim Memorial Foundation, Aug. 11, 1928; American Fund for Public Service, Imperialism Committee to W. E. B. Du Bois, ca. Jan. 10, 1929; W. E. B. Du Bois to Julius Rosenwald Fund, Dec. 19, 1930, all in Du Bois Papers, U-Mass.

${ }^{74}$ Carter G. Woodson to W. E. B. Du Bois, Apr. 28, 1924, Du Bois Papers, U-Mass.

${ }^{75}$ W. E. B. Du Bois to James Dillard, Sept. 27, 1927, Du Bois Papers, U-Mass.

${ }^{76}$ Du Bois, "The Black Man and the Wounded World," 114.

${ }^{77}$ The Black Man and the Wounded World, Subscriptions, folders 6-11, box 1, Du Bois Collection, Fisk.
} 
the April 1924 issue of The Crisis. ${ }^{78}$ In what amounted to his most creative idea, Du Bois also discussed with Colonel Otis B. Duncan the possibility of presenting the study to the general public in the form of a pageant to be held in the Eighth Illinois National Guard armory in Chicago. The production, as proposed by $\mathrm{Du}$ Bois, was to be quite a spectacle, complete with "soldiers, children and finally masses of little dolls," reminiscent of his initial foray into stage production with "The Star of Ethiopia." ${ }^{79}$ These efforts spoke to Du Bois's intertwined artistic and historical imagination, as well as a determination to have his work reach the public in some way, shape, or form.

As Du Bois grappled with the meaning of the war during the 1920s, many white historians did the same. A mood of disenchantment replaced the initial optimism of progressive journalists and historians in the wake of the anticlimactic conclusion of the Paris Peace Conference and skepticism about the effectiveness of the League of Nations. The question of who deserved blame for the start of the war soon emerged as the most contentious debate within the historical profession. In a May 1924 article for Current History, Harry Elmer Barnes of Columbia University attempted to debunk the near universally accepted "scape-goat theory" that Germany alone brought on the war. He argued, instead, that the true culprit was "the wrongheaded and savage European system of nationalism, imperialism, secret diplomacy and militarism which sprang into full bloom from 1870-1914"-an interpretation that Du Bois had offered as early as 1915, and to much less fanfare. ${ }^{80}$ Two years later, Barnes's book, Genesis of the World War, shifted responsibility for the war to France and Russia. Revisionists praised the controversial book, while traditionalists such as Albert Bushnell Hart and Bernadotte Schmidt, a professor of history at the University of Chicago, denounced it. Smith College professor Sidney Fay, respected by historians on both sides of the quarrel, hoped to calm the waters with his eagerly anticipated study Origins of the World War (1928). Soon the conversation shifted to the question of American intervention, with Barnes again stoking the fire and his former student, Clinton Hartley Grattan, jumping into the fray with Why We Fought (1929). The revisionist interpretation held sway as the nation entered the Great Depression. By the mid-1930s, the First World War, as some historians already called it, was widely seen as a failure, and the United States's role it in a grave mistake. ${ }^{81}$

While not part of the mainstream historical profession, Du Bois was well aware of and immersed in the controversies concerning historical objectivity, propaganda, and the ultimate meaning of the war. In 1930, Du Bois was pulled into this larger debate when Kirby Page, editor of the magazine The World Tomorrow, asked him to participate in a forum on the theme of "War Guilt," which included prominent journalists, editors, and nearly every major historian in the profession. Page sent Du Bois four questions: "Do you believe that Germany and her allies were solely responsible for causing the World War?" "Do you believe that Germany was more responsible than any other Power for causing the World War?" "Do you favor all round cancellation of war debts and reparations?" "In the light of all the evidence now available, do you think the United States acted wisely in entering the war against Germany?" ${ }^{2}$ Du Bois offered an unusually forthcoming response that did not explicitly address the questions posed by Page, but allowed him to explain his own personal connection to the war guilt dilemma. "I think your questionnaire on war guilt is important," Du Bois explained, because it provided an

\footnotetext{
${ }^{78}$ W. E. B. Du Bois, “The Story of the War," The Crisis 28, no. 1 (May 1924): 1-48, here 36-8.

${ }^{79}$ W. E. B. Du Bois to Otis B. Duncan, June 19, 1923, Du Bois Papers, U-Mass.

${ }^{80}$ Harry Elmer Barnes, "Assessing the Blame for the World War: A Revised Judgement Based on All the Available Documents," Current History 20 (May 1924): 171-95. For more on Barnes, see Roy Turnbaugh, "Harry Elmer Barnes and World War I Revisionism: An Absence of Dialogue," Peace \& Change 5, nos. 2-3 (Oct. 1978): 63-9.

${ }^{81}$ Novick, That Noble Dream, 207-24.

82"War-Guilt Soundings: A Summary of 429 Opinions," "Symposium on War Responsibility," "Found Guilty!," "The Case Reopened," The World Tomorrow, Oct. 1930, 395-405.
} 
opportunity to demonstrate that "intelligent human beings change their minds." "I know this is true in my own case," he added. Du Bois confessed that while he "knew something of German militarism and greatly feared it," at the time he was not aware of the "manipulations of the English and French in international intrigue." He further admitted to being "swept off my feet during the world war by the emotional response of America to what seemed to be a great call to duty." He did not appreciate, in the midst of nationalist fervor, "how easy and inevitable it is for an appeal to blood and force to smash to utter negation any ideal for which it is used." Echoing the conclusions of his forthcoming book, Du Bois wrote, "Instead of a war to end war, or a war to save democracy, we found ourselves during and after the war descending to the meanest and most sordid of selfish actions, and we find ourselves today nearer moral bankruptcy then we were in 1914." Then, with eye-opening introspection, he stated, "I am ashamed of my own lack of foresight, and yet war is so tremendous and terrible a thing that only those who actually experience it, can know its real meaning." 83 More than with any previous statement, Du Bois here acknowledged his error in supporting the war, yet still sought to rationalize his decision by casting himself as a victim of its seemingly endless horrors. Page edited Du Bois's response for final publication, omitting, no doubt to Du Bois's satisfaction, his admission of shame. ${ }^{84}$

Even as Du Bois turned to other projects, The Black Man and the Wounded World and the history of the war remained on his mind. Never content with being unproductive, Du Bois published the historical survey The Gift of Black Folk (1924), the novel Dark Princess (1928), and his most notable published work of history, Black Reconstruction (1935). But even Black Reconstruction must be viewed in relation to his fixation on World War I. In a letter to Alfred Harcourt proposing Black Reconstruction in 1931, Du Bois informed the editor, "I am going to add next year as a second volume 'The Black Man and the Wounded World'; that is, the part which Negro troops took in the World War and its significance for the world today." ${ }^{85} \mathrm{Du}$ Bois clearly envisioned a direct connection between these two defining moments in the history of the color line. As he wrote in Black Reconstruction, "If the Reconstruction of the Southern democracy, from slavery to free labor, and from aristocracy to industrial democracy, had been conceived as a major national program of America, whose accomplishment at any price was well worth the effort, we should be living today in a different world." 86 In his view, the nation's failure to fulfill the democratic promises of Reconstruction led to the creation of the so-called "race problem," a problem that by World War I had metastasized into a global system of social, political, and economic oppression. Harcourt responded to Du Bois that the proposed study on Reconstruction "promises a really interesting book." He made no mention of the book on the World War. ${ }^{87}$

Following the publication of Black Reconstruction, Du Bois again returned to The Black Man and the Wounded World. A glimmer of hope appeared in March 1935 when he secured a \$600 grant from the Social Science Research Council. ${ }^{88}$ By this time Du Bois's politics had moved further to the left and he envisioned the book, as articulated in a January 1936 funding request to the Carnegie Endowment for Inter-Racial Peace, as an explicitly anti-war tract. "The unnecessary suffering and intrigue, the effect of the war upon the Negro peoples today, the Italian-Ethiopian aftermath," Du Bois explained, "all makes me certain that I could write a volume which would be an effective attack upon the war from the point of view of the so-called lesser peoples." 89 In late 1936, thanks to a fellowship from the Oberlaender Trust, Du Bois

\footnotetext{
${ }^{83}$ W. E. B. Du Bois to the World Tomorrow, June 24, 1930, Du Bois Papers, U-Mass.

84"Symposium on War Responsibility," The World Tomorrow, Oct. 1930, 399.

${ }^{85}$ W. E. B. Du Bois to Alfred Harcourt, Sept. 23, 1931, Du Bois Papers, U-Mass.

${ }^{86}$ W. E. B. Du Bois, Black Reconstruction in America, 1860-1880 (New York, 1935; New York, 1995$), 708$.

${ }^{87}$ Alfred Harcourt to W. E. B. Du Bois, Oct. 6, 1931, Du Bois Papers, U-Mass.

${ }^{88}$ Social Science Research Council to W. E. B. Du Bois, Mar. 20, 1935, Du Bois Papers, U-Mass.

${ }^{89}$ W. E. B. Du Bois to James Shotwell, Jan. 16, 1936, Du Bois Papers, U-Mass.
} 
spent several months abroad, visiting Germany, England, France, Switzerland, Austria, Russia, China, and Japan. He returned to the United States, having seen first-hand the next World War on the horizon, with an added sense of urgency to complete the book. He reached out to the American Philosophical Society in March 1937 and requested \$7,500 to finally put the project behind him. "I began my work in this field as a conventional study of the Negro as a soldier in the World War," he wrote, "and the arrangement of these facts would have made a book ready for publication many years ago." But over time, he explained, "the whole theme has been expanding and developing in my mind, more especially since my trip around the world in 1936." He now conceived the book "on a much broader and more important scale." If only he could "have leisure and opportunity to finish this work," Du Bois pleaded, "I think I can do something which will have influence on future knowledge with regard to war and colored people." The American Philosophical Society denied his request and, with this final rejection, Du Bois abandoned hope that the Black Man and the Wounded World, despite an investment of almost twenty years and a manuscript nearly 800 pages in length, would ever see the light of day. ${ }^{90}$

\section{Du Bois and the Troubling Memory of World War I}

Du Bois's inability to complete The Black Man and the Wounded World represented one of the biggest intellectual regrets of his life. In his semi-autobiographical book Dusk of Dawn (1940), he lamented, "The whole history of the American Negro and other black folk in the World War, has never been written." He recalled his time in France and the "mass of documents" he had collected over the years. "They deserve publication," he wrote, "not simply as a part of the Negro's history, but as an unforgettable lesson in the spiritual lesions of race conflict during a critical period of American history. I hope sometime that a careful history based on these documents may see the light." 91 The "spiritual lesions" left on the world by the war had yet to heal. His own wounds had not healed, either. "I did not realize the full horror of war and its wide impotence as a method of social reform," he reflected.

Perhaps, despite words, I was thinking narrowly of the interest of my group and was willing to let the world go to hell, if the black man went free. Today I do not know; and I doubt if the triumph of Germany in 1918 could have had worse results than the triumph of the Allies. Possibly passive resistance of my twelve millions to any war activity might have saved the world for black and white. Almost certainly such a proposal on my part would have fallen flat and perhaps slaughtered the American Negro body and soul. I do not know. I am puzzled. ${ }^{92}$

Du Bois suffered from intellectual shell shock when it came to rationalizing a war defined by its irrationality. $^{93}$

This inability to grasp the full personal and historical significance of the war seeped into the final years of his life. "I felt for a moment as the war progressed that I could be without reservation a patriotic American," Du Bois wrote in an autobiography published posthumously in 1968. "I am not sure that I was right but certainly my intentions were. I did not believe in war, but I thought that in a fight with America against militarism and for democracy we would be fighting for the emancipation of the Negro race. With the Armistice came disillusion." $\mathrm{He}$

\footnotetext{
${ }^{90} \mathrm{Du}$ Bois grant submission to the American Philosophical Society, Mar. 9, 1937; American Philosophical Society to Du Bois, Mar. 11, 1937; American Philosophical Society to Du Bois, Apr. 12, 1937, folder 33, box 14, Du Bois Collection, Fisk.

${ }^{91}$ Du Bois, "Dusk of Dawn" in W. E. B. Du Bois: Writings, 746.

${ }^{92}$ Ibid., 740-1.

${ }^{93}$ On the irrationality of the war, see Paul Fussell, The Great War and Modern Memory (New York, 1975).
} 
recalled seeing "the mud and dirt of the trenches" in France just after the war, and hearing "from the mouths of soldiers the kind of treatment that black men got in the American army." He came away convinced that "American white officers fought more valiantly against Negroes within our own ranks than they did against the Germans." "I still believe this was largely true," he offered in one final historical opinion before his death. ${ }^{94}$

The war haunted Du Bois. His deep personal connection to this watershed moment, combined with tortured memories, only made attempting to historicize it that much more daunting. He had supported the Allied war effort. He had encouraged African Americans to enlist and offer their unconditional loyalty. He had defended the record of black soldiers and officers in the face of slanderous attacks. Du Bois desperately wanted to believe he was right, that it had all been worthwhile. However, confronted with nearly twenty years of evidence, deep down he knew he was wrong, and his hopes for a world in which black people would have freedom and democratic rights misplaced. In this sense, the "black man and the wounded world" was Du Bois himself.

But Du Bois's decades-long engagement with the history of the World War constituted much more than just an attempt at personal redemption. Through his many writings, published and unpublished, he challenged racist interpretations of the war that cast African Americans and other peoples of African descent as marginal actors, or absent from the great drama of 1914-1918 altogether. He understood the war's significance as a truly global conflict with a level of sophistication and prescience that scholars today are only now beginning to match. His work also speaks to the need for historians to marshal the tools of their own imagination in exploring the war's complicated legacy. As he wrote in his funding request to the American Philosophical Society, "The World War was an occurrence which calls for broader study." ${ }^{95}$ What Du Bois declared in 1937 remains true today.

Chad Williams is associate professor and chair of the Department of African and Afro-American Studies at Brandeis University. He specializes in African American and modern United States history, World War I, and African American intellectual history. His book Torchbearers of Democracy: African American Soldiers in the World War I Era (2010) received the 2011 Liberty Legacy Foundation Award from the Organization of American Historians, the 2011 Distinguished Book Award from the Society for Military History, and designation as a 2011 CHOICE Outstanding Academic Title. He is currently completing a study of W. E. B. Du Bois and the history of World War I.

\footnotetext{
${ }^{94}$ Du Bois, Autobiography of W. E. B. Du Bois, 274.

${ }^{95} \mathrm{Du}$ Bois grant submission to the American Philosophical Society, Mar. 9, 1937, folder 33, box 14, Du Bois Collection, Fisk.
} 